\title{
The contribution of natural and artificial regeneration at the restoration of fire-affected peri-urban forest of Thessaloniki (Northern Greece)
}

\author{
Chatzichristaki Ch.* and Zagas Th. \\ Thessaloniki, Greece, \\ Received: 29/08/2015, Accepted: 20/01/2017, Available online: 14/02/2017 \\ *to whom all correspondence should be addressed: \\ e-mail: xrysxat@gmail.com
}

Laboratory of Silviculture, Faculty of Forestry \& Natural Environment, Aristotle University of Thessaloniki, P.O. BOX 262, 54124

\begin{abstract}
In this study, the post-fire regeneration of three coniferous species (Pinus brutia, Cupressus sempervirens and Cupressus arizonica) was examined in the peri-urban forest of Thessaloniki, Northern Greece. The wildfire took place in July 1997 and burned almost 60\% of the forest vegetation. During the autumn of 2010, 34 experimental plots were established in all aspects within the burned area. In each experimental plot the following measurements were carried out: height, diameter at breast height and crown projection in two perpendicular diameters. The results show that the Pinus brutia individuals, most of which came from natural regeneration, presented the best growth, in relation to the two other species in all aspects. As for Cupressus sempervirens, equal parts of which came from natural and artificial regeneration was characterized by remarkable growth especially in the Northeastern aspect. Finally, Cupressus arizonica existed in all aspects except the Northeastern. It also presented a satisfactory development, especially on the Southern aspect. Fourteen years after the fire pure or mixed stands of the above mentioned species show vigorous growth and good stem quality. Finally, the rates of participation of individual forest species indicate that the restoration has been achieved mainly by natural regeneration.
\end{abstract}

Keywords: Postfire reforestation, Pine forest, Wildfire

\section{Introduction}

Forest fires are an integral part of Mediterranean forest ecosystems (Naveh 1991; Pausas et al., 2008). Mediterranean forests and especially pinewoods have often been the target of arson. They have been characterized as the most vulnerable forest ecosystems on earth due to climatic conditions (hot and dry summer), the intense and extensive pressure by humans and the recurring fires (Vallejo 2005; Palahi and Birot 2009). Pine species have developed mechanisms to regenerate naturally after fire (Trabaud 1994; Pausas and Vallejo
1999). Fire is also a particularly relevant ecological factor to the regeneration of Mediterranean forests.It has been estimated that $0.5-1 \%$ of Mediterranean forests are affected by fire every year (Bengtsson et al., 2000).

In Greece, fires occur mainly in areas that are dominated by Mediterranean type vegetation, which cover up to $40 \%$ of the terrestrial vegetation of the country (Arianoutsou 1984). This type of vegetation, besides pine forests, also includes two different Mediterranean ecosystems, maquis and phrygana, that are well known to be highly flammable (Tsitsoni et al., 2004; Zagas 2008).

During the last 30 years, destructive fires burned millions of hectares of pine forest within Greece. The most devastating incidents took place in Lesvos 1982 and Ikaria 1993 (Kailidis, 1997), Samos 1983 (Thanos et al., 1989; Thanos and Doussi, 2000), Attika (mt. Pateras) 1984 (Zagas 1987) and Parnitha 2008, Thasos 1985 and 1989 (Spanos et al., 2000; Spanos et al., 2001), Thessaloniki (Kedrinos lofos) 1997 (Spanos et al., 2000; Tsitsoni et al., 2004), Kassandra 1990 and 2006, Peloponnese and Evia 2008.

Many studies mention that the post-fire natural regeneration of Pinus brutia in Greece is sufficient (Dafis 1987; Thanos et al., 1989; Spanos, 1992; Tsitsoni et al., 2004; Spanos et al., 2010). However, the first post-fire wet season is particularly significant since it is the time period that seed germination takes place and seedlings emerge (Ozdemir 1977; Spanos and Spanos 1996; Spanos et al. 2000; Boydak 2004). Despite the fact that site quality and aspect influence pine forests regeneration, seedlings density constitutes another crucial factor (De Las Heras et al., 2004).

It is widely accepted that forest restoration is a global concept that may have different degrees and intensities of management intervention, depending on the degradation stage of the forest and the specific management objectives considered (Moreira et al., 2012). The restoration of fire 
affected ecosystems can be achieved both by natural and artificial methods.

Natural regeneration can be either passive or assisted. Passive restoration is based on the protection of the area from further disturbances and to the enhancement of ecological succession process (Lamb and Gilmour, 2003). Regeneration in burned areas may occur from seeds (Pausas et al., 2004), from resprouting of burned trees and stumps (Espelta et al., 2003) or resprouting of burned shrubs and herbs (Stephan et al., 2010). Tree resprouts, in particular, have significant advantages over seedlings or planted trees because they have an already established root system which may offer higher probability of survival and better growth (Moreira et al., 2009). Post-fire rehabilitation treatments include assisted restoration and may involve thinning, selection of shoots in coppices and control of unwanted vegetation or protection from grazing animals (Lamb and Gilmour, 2003; Moreira and Vallejo, 2009).

Artificial regeneration techniques include plantations and direct seeding which can contribute to the improvement of soil properties and site productivity (Dafis, 1991; Zagas et al., 1998).These are relatively expensive methods for restoration (Moreira et al., 2009). The survival of planted seedlings is quite variable and often quite low in the case of broadleaved trees (Pausas et al., 2004).

The main objectives of the present study were: i) to identify the stands composition per aspect and ii) to determine the growth of natural and artificial regenerated coniferous species in different aspects, fourteen years after the wildfire.

\section{Material and methods}

\section{Study area}

The study was conducted at the peri-urban forest of Thessaloniki, named "Kedrinos lofos". It is composed mainly from reforestations of Pinus brutia and Cupressus sempervirens. It is located at the north-eastern side of the city and constitutes a unique source of oxygen, a recreation area, a place for environmental education and research. The forest occupies an area of 3,018.84 ha and 1,664 ha (approximately 60\%), were destroyed from the 1997 forest fire. The area is characterized as hilly and semimountainous, altitude ranges from $60 \mathrm{~m}$ to $560 \mathrm{~m}$ asl and the slope inclination ranges from $20 \%$ to $50 \%$, while in many areas becoming smoother (15\%).

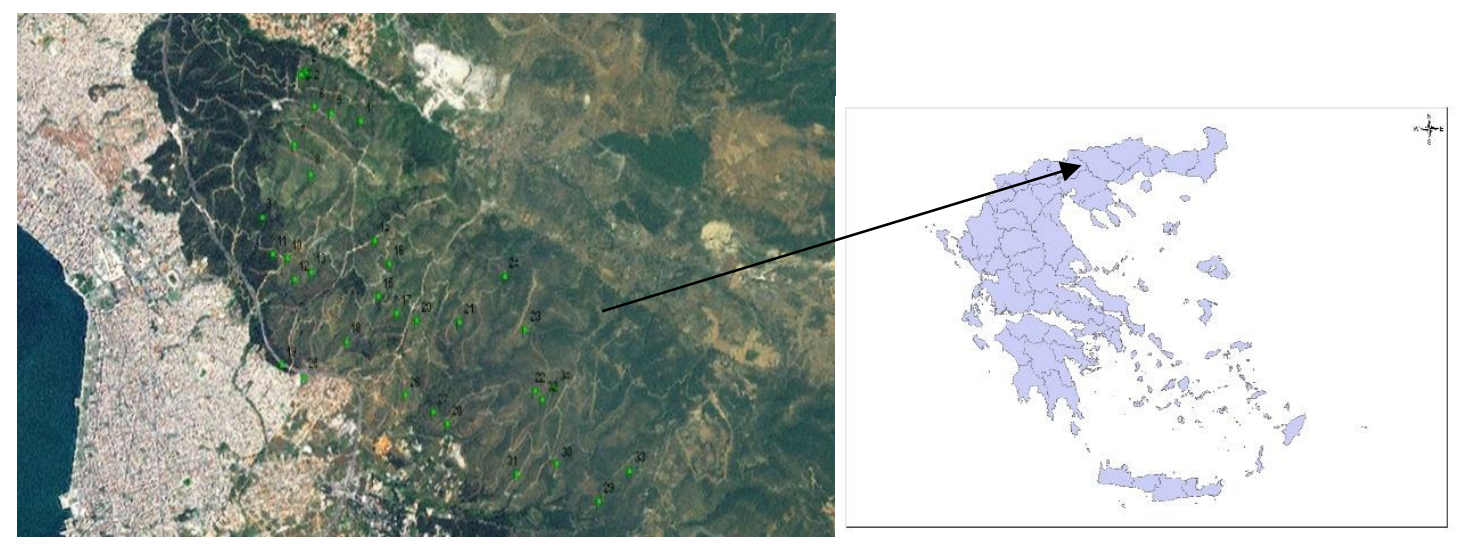

Figure 1.The distribution of sample plots in the research area

Meteorological data for the long term period 1946-2007 were collected from the meteorological station of the Aristotle University of Thessaloniki, which is located at an altitude of $40 \mathrm{~m}$. The distance of the meteorological station from the study area is $3 \mathrm{~km}$. According to the classification of Köppen (1931) the climate of the region belongs to the Csa category, which means "Typical Mediterranean climate with dry and hot summer".

The mean annual precipitation is $449.3 \mathrm{~mm}$ and the mean annual temperature is $15.9{ }^{\circ} \mathrm{C}$. According to the Emberger (1959) bioclimatic diagram, the region has pluviothermic quotient (Q) of 54.6. Based on Emberger the areas bioclimate is wet and semi-arid, and so it may have low fertility and productivity for the growth of forests especially at the Southern aspect where in conjunction with the shallow depth of soil, it creates unfavorable growth conditions, even for xerothermic species.

The vegetation of the area belongs to the lowest part of the Mediterranean vegetation zone Quercetalia pubescentis and specifically to the sub-zone Ostryo-Carpinion and the association Coccifero Carpinetum (Spanos et al., 2000; Tsitsoni et al., 2004; Spanos et al., 2010).

After the destructive fire of 1997, half of the burnt area (800ha) was planted with several forest species while the rest of the area regenerated naturally. In the reforestations apart from coniferous species, and especially Cupressus arizonica, broadleaved species were also used in order to convert the existing pure pine stands into mixed stands. The vegetation composition included both native species of the region and some artificially introduced species. Pinus brutia comprises mainly the overstory either as pure stands or in mixed with Cupressus sempervirens. From the artificially introduced species, Cupressus arizonica is the most common and individuals of Pinus halepensis and Pinus pinea are rarely encountered.

As for the understory the most common species are Quercus coccifera, Paliurus spina-christi and Cistus incanus in medium site qualities, whereas in good site qualities 
Crategus monogyna, Fraxinus ornus and Ulmus campestris also exist (Tsitsoni et al., 2004; Spanos et al., 2010).

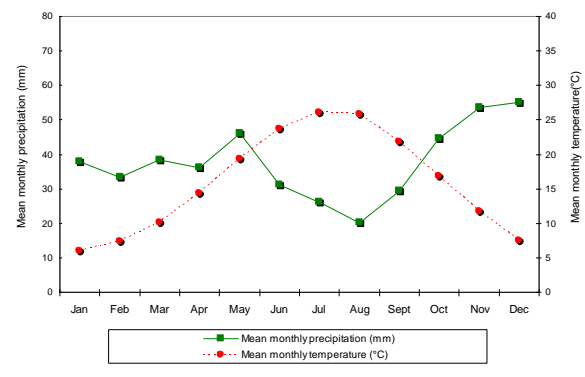

Figure 2. Ombrothermic climatic diagram of Aristotle University meteorological station

\section{Methods}

In order to evaluate the progress of the natural and artificial regeneration and their contribution to the restoration of the fire affected area, the following methodology was applied. Initially the burned area was mapped and field data were collected. In order to achieve the goals of the current research, 34 sample plots of $100 \mathrm{~m}^{2}$ $\left(10 m^{*} 10 m\right)$ were randomly established proportionally according to the aspect. Moreover, the location of each sample plot was recorded using GPS (MobileMapper 6 of Magellan) with accuracy $1 \mathrm{~m}$ and the slope orientation has been defined by using a compass.

In each sample plot the number of individuals was recorded for all species. In all individuals the following measurements were carried out: total height $(H, m)$, diameter $(\mathrm{DBH}, \mathrm{cm})$ at breast height for trees over $2 \mathrm{~m}$ height and at root collar for seedlings. Furthermore, crown projection was recorded with two perpendicular diameters (North-South and East-West) and their average was utilized to calculate the radius of crown for each tree.

Also qualitative characteristics, such as tree vitality (V) and developmental tendency (DT), were assessed based on the IUFRO classification (Leibundgut, 1959).

Tree vitality $(\mathrm{V})$ is classified in three classes:

10 , for trees of vigorous growth

20 , for trees of normal growth and

30 , for trees of declining growth.

Developmental tendency is also classified in three classes:

1 : improving growth, dominance likely to increase

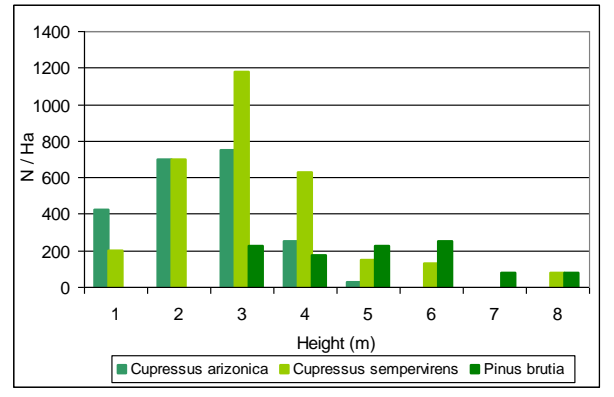

2 : stationary, no change compared with nearest neighbors'

3 : descendant growth.

The relationship among the number of seedlings, diameter, height and crown projection on the one hand, and the influence of aspect on the other was investigated by applying the analysis of variance (one-way ANOVA). The significance of the results was tested using the Duncan test (Norusis, 1994). Additionally, data was analyzed statistically (descriptive statistics, means and standard errors of means, correlation between measuring characteristics) using SPSS ver.15 statistical program. It should be noted that broadleaved species were not considered due to their remarkably low participation within the study area (below 7\%).

\section{Results}

\subsection{Structure and composition of stands}

From the results it appeared that Pinus brutia was the dominant species in all sample plots $(58.7 \%)$ and the ones following were Cupressus sempervirens and Cupressus arizonica with $22.5 \%$ and $18.6 \%$ respectively. An evenaged coniferous forest was formed fourteen years after the destructive fire. The regenerated forest is presently in the sapling stage.

The average density of individuals ranged from 6,225 $\mathrm{N} \mathrm{ha}{ }^{-1}$ in the Northern aspect to $2,500 \mathrm{~N} \mathrm{ha}^{-1}$ in the Northwestern aspect. It should be mentioned that in the Northeastern aspect stand individuals of Cupressus arizonica were missing. Also, Cupressus sempervirens showed a low participation (5\%) in the Southwestern aspect stands. However, both of these species showed sufficient development.

\subsection{Composition and evolution of species per aspect}

\subsubsection{Northern aspect stands}

The stands on the northern aspect were dominated by Cupressus sempervirens, 3,050 $\mathrm{N} \mathrm{ha}^{-1}$, and Cupressus arizonica, 2,150 $\mathrm{N} \mathrm{ha}^{-1}$. Individuals of Pinus brutia had low participation $\left(1,025 \mathrm{~N} \mathrm{ha}^{-1}\right)$.

It is worth noting that despite the small percentage in the stand mixture, Pinus brutia individuals exhibited the best growth in all aspects as the average value of height was $4.52 \mathrm{~m}$. The density of seedlings was higher at the middlestorey (61.04\%).

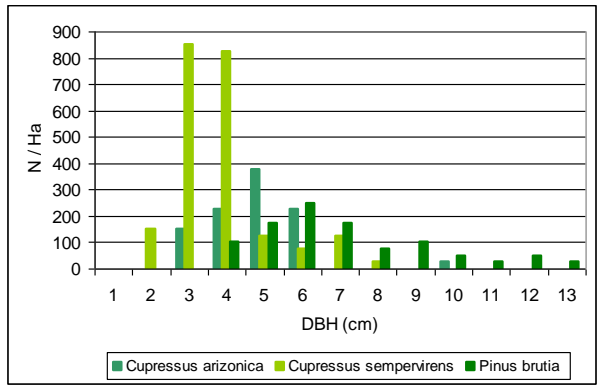

Figure 3. Distribution of height and diameter classes of the mixed stands on northern aspects 
Most of them showed normal growth with mean values for vitality from 14.63 to 17.29 and for developmental tendency from 1.31 to 1.63 . The distributions of height and diameter of the above species on the Northern aspects can be seen in figure 3.

\subsubsection{North-eastern aspect stands}

At the stands of North-eastern aspect totally $5,800 \mathrm{~N} \mathrm{ha}^{-1}$ were recorded. These stands consisted of individuals of Pinus brutia and Cupressus sempervirens, 5,033 $\mathrm{N} \mathrm{ha}^{-1}$ and

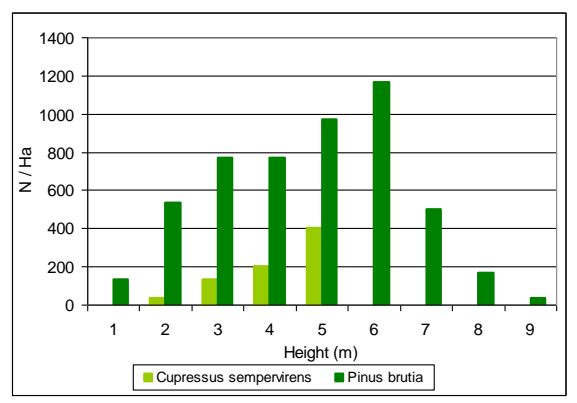

$767 \mathrm{~N} \mathrm{ha}^{-1}$ respectively.It was also observed that individuals of Cupressus arizonica were missing in these aspects, because this species is non-native and its entire population came from artificial regeneration. The majority of individuals were in the middle-storey. Mean values for vitality and developmental tendency ranged from 19.13 to 19.73 and 1.74 to 1.91 respectively. The stems were well distributed in height and diameter, as presented in figure 4.

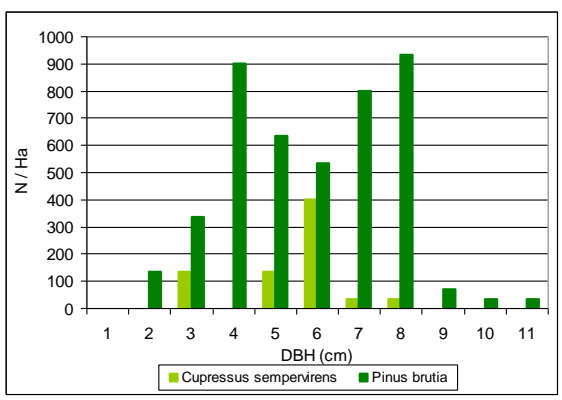

Figure 4. Distribution of height and diameter classes of the mixed stands on north-eastern aspects

\subsubsection{North-western aspect stands}

The stands on the North-western aspect had the lowest density of seedlings. Regarding the stand mixture, it was calculated that the involvement of Pinus brutia, Cupressus sempervirens and Cupressus arizonica was $67.2 \%, 31.2 \%$ and $1.6 \%$ respectively. Approximately $50 \%$ of individuals were in the middle-storey and mean values for vitality and developmental tendency did not indicate favorable growth in comparison with other aspects (10 to 15.11 and 1 to 1.33, respectively). In figure 5 can be seen the distribution of height and diameter classes.

\subsubsection{Southern aspect stands}

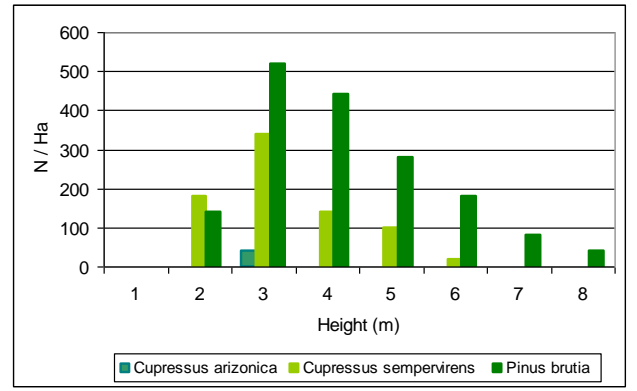

Figure 5. Distribution of height and diameter classes of the stands of North-western

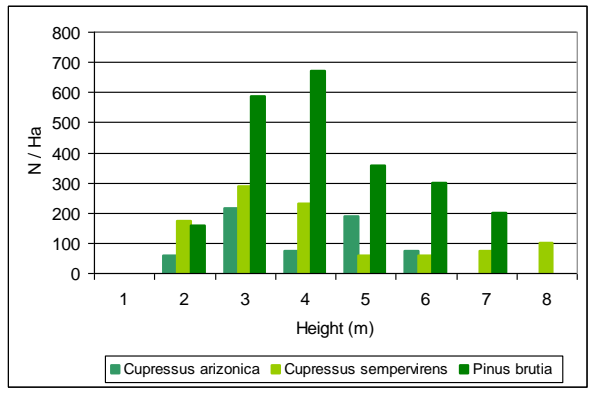

The density of seedlings on the Southern aspect stands was $3,844 \mathrm{~N}$ ha ${ }^{-1}$. Pinus brutia had a significant seedlings number of 2,272 $\mathrm{N} \mathrm{ha}^{-1}$, while the participation of Cupressus sempervirens and Cupressus arizonica was $972 \mathrm{~N}$ $\mathrm{ha}^{-1}$ and $600 \mathrm{~N}$ ha ${ }^{-1}$ respectively. Despite the small participation, Cupressus arizonica exhibited impressive growth at this aspect and the average value height was 3.47 $\mathrm{m}$. After all, average values for vitality ranged from 13.33 to 18.2 and for developmental tendency from 1.35 to 1.53 . Height and diameter classes' distribution is presented in figure 6 .
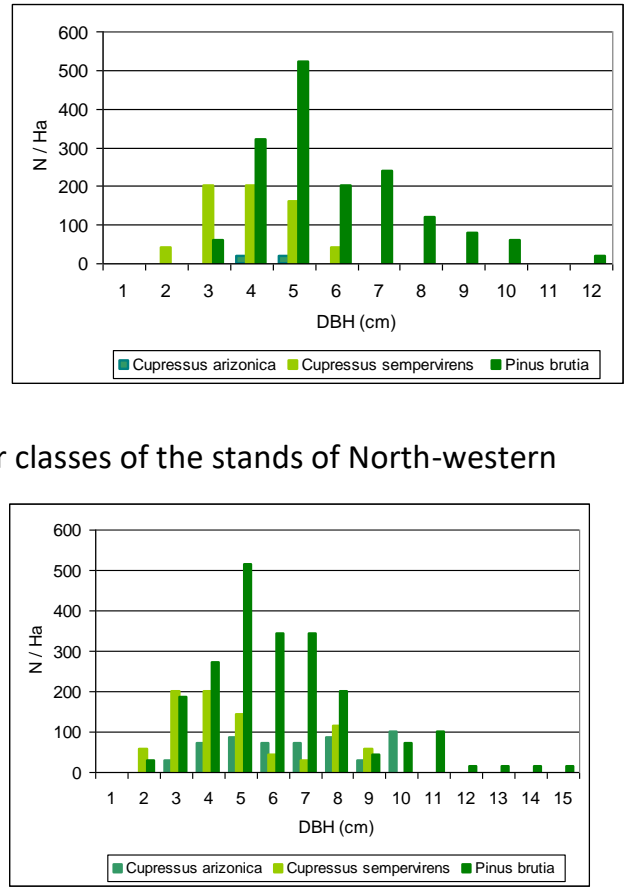

Figure 6. Distribution of height and diameter classes of mixed stands on Southern aspects 


\subsubsection{South-eastern aspect stands}

The stands condition on the South-eastern aspect was remarkably similar to Southern ones. Between these aspects the number of individuals did not vary significantly. However it is worth mentioning that, apart from Pinus brutia individuals, the other two species had notable differences regarding their average height values. As for Cupressus sempervirens the mean height was lower than in the Southern aspect, $2.05 \mathrm{~m}$ and $3.71 \mathrm{~m}$ respectively. Cupressus arizonica showed similar growth with mean values for height $2.36 \mathrm{~m}$ and $3.47 \mathrm{~m}$ respectively. Furthermore, the values for vitality ranged from 14.74 to 17.46 and for developmental tendency from 1.4 to 1.69 .

\subsubsection{South-western aspect stands}
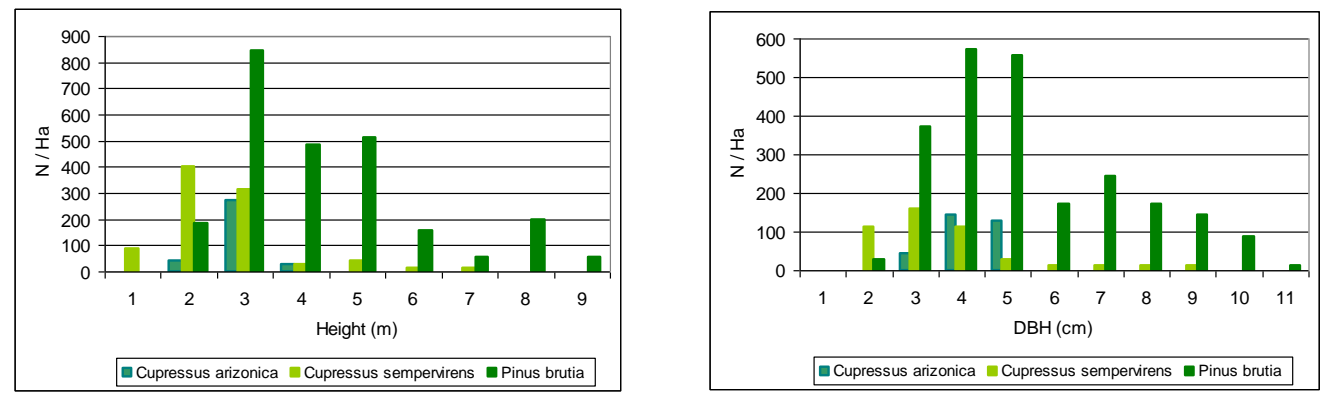

Figure 7. Distribution of height and diameter classes on South-eastern aspects
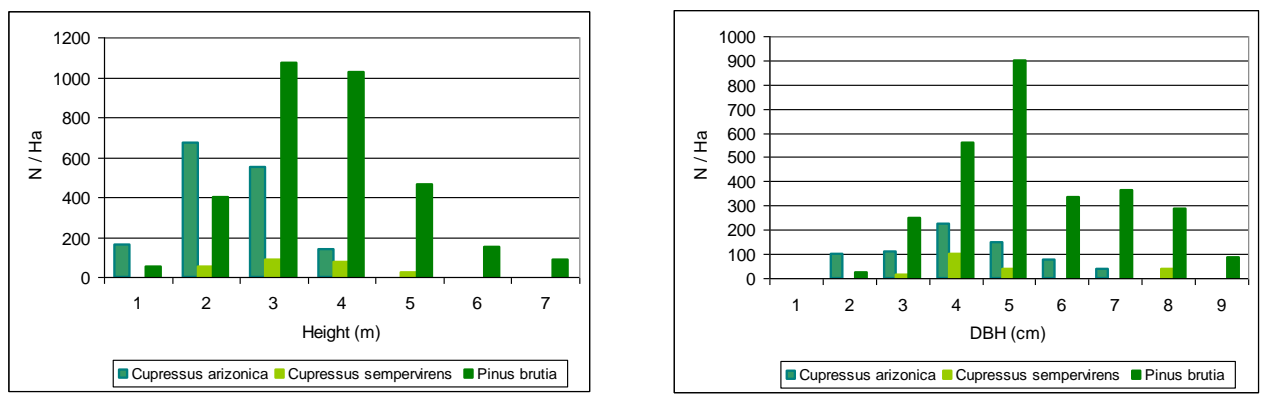

Figure 8. Distributions of height and diameter classes of mixed stands on South-western aspects.

\subsubsection{Effect of site aspect on growth}

Analysis of variance was applied for each species separately, in order to study their growth under the influence of different aspects. The average height of Pinus brutia on the North aspect was $4.52 \mathrm{~m}$ and had the greatest growth in comparison to the other aspects, as their values ranged from $3.2 \mathrm{~m}$ to $4.17 \mathrm{~m}$. Diameter at breast height (DBH) showed the same trend. North aspects had higher DBH value $(6.5 \mathrm{~cm})$ and the lower one was on
Finally, with regard to South-western aspect stands, despite the fact that it is considered a poor aspect for species growth (Spanos et al., 2000), an increased participation of seedlings of all species was exhibited, 5,013 $\mathrm{N} \mathrm{ha}{ }^{-1}$ in total. It is remarkable that Cupressus sempervirens presented the lowest participation compared to other aspects, $238 \mathrm{~N} \mathrm{ha}^{-1}$, but their growth was almost similar to Northern and North-eastern aspects. However, the total growth of the three species was sufficient and $51.6 \%$ of them were concentrated at the middle-storey. Lastly, vitality and developmental tendency indicated normal growth as well as their values ranged from 16.5 to 18.19 and from 1.42 to 1.56 respectively.

Table 1. Effect of aspect on height, diameter at breast height (DBH) and crown projection of Pinus brutia.

\begin{tabular}{cccc}
\hline ASPECT & Height $(\mathbf{m})$ & DBH (cm) & Crown projection $\left(\mathbf{m}^{2}\right)$ \\
\hline SW & $3.20(0.71) \mathrm{a}$ & $4.89(0.10) \mathrm{a}$ & $2.44(0.08) \mathrm{a}, \mathrm{b}$ \\
\hline NW & $3.64(0.15) \mathrm{b}$ & $5.29(0.20) \mathrm{a}, \mathrm{b}$ & $2.97(0.21) \mathrm{b}, \mathrm{c}, \mathrm{d}$ \\
\hline $\mathrm{S}$ & $3.80(0.10) \mathrm{b}, \mathrm{c}$ & $5.61(0.18) \mathrm{b}$ & $3.48(0.19) \mathrm{d}$ \\
\hline SE & $3.89(0.14) \mathrm{b}, \mathrm{c}$ & $5.44(0.25) \mathrm{a}, \mathrm{b}$ & $3.19(0.13) \mathrm{c}, \mathrm{d}$ \\
\hline NE & $4.17(0.14) \mathrm{c}, \mathrm{d}$ & $5.33(0.16) \mathrm{a}, \mathrm{b}$ & $2.65(0.19) \mathrm{a}, \mathrm{b}, \mathrm{c}$ \\
\hline $\mathrm{N}$ & $4.52(0.24) \mathrm{d}$ & $6.5(0.36) \mathrm{c}$ & $2.31(0.18) \mathrm{a}$
\end{tabular}

Values within the same column followed by different letter are statistically different $P<0.05$, Duncan test.

Northwestern aspects $(\mathrm{DBH}=4.89 \mathrm{~cm})$. Although, crown projection presented an entirely different development as the higher values appeared on South aspect stands and followed by $\mathrm{SE}>\mathrm{NW}>\mathrm{NE}>\mathrm{SW}>\mathrm{S}$. The correlation between height and $\mathrm{DBH}$ was particularly strong for Pinus brutia individuals $\left(r^{2}=0.73\right)$. Furthermore, the correlation between height and crown projection was $r^{2}=0.67$ and the correlation between $\mathrm{DBH}$ and crown projection was less strong $\left(r^{2}=0.58\right)$.

Values within the same column followed by different letter are statistically different P<0.05, Duncan test. 
Regarding Cupressus sempervirens, statistically significant differences were exhibited for the tested parameters. The highest value of average height and diameter at breast height appeared on the Northeastern aspect $(\mathrm{H}=3.74 \mathrm{~m}$, $\mathrm{DBH}=4.83 \mathrm{~cm}$ ) whereas the lowest on the Southeastern aspect $(\mathrm{H}=2.05 \mathrm{~m}, \mathrm{DBH}=3.16 \mathrm{~cm})$. Crown projection appeared quite different with mean values on the Southwestern aspect $1.36 \mathrm{~m}^{2}$ and $0.47 \mathrm{~m}^{2}$ on the Northwestern aspect. Also, significant correlation was exhibited between height and DBH $\left(r^{2}=0.80\right)$ while no significant correlation was detected between height and crown projection or crown projection and $\mathrm{DBH}$.

Table 2. Effect of aspect on height, diameter at breast height (DBH) and crown projection of Cupressus sempervirens.

\begin{tabular}{cccc}
\hline ASPECT & Height $(\mathbf{m})$ & DBH $(\mathbf{c m})$ & Crown projection $\left(\mathbf{m}^{2}\right)$ \\
\hline SE & $2.05(0.13) \mathrm{a}$ & $3.16(0.29) \mathrm{a}$ & $0.68(0.07) \mathrm{a}$ \\
\hline $\mathrm{SW}$ & $2.69(0.20) \mathrm{b}$ & $4.41(0.40) \mathrm{b}$ & $1.36(0.23) \mathrm{c}$ \\
\hline $\mathrm{NW}$ & $2.71(0.16) \mathrm{b}$ & $3.38(0.17) \mathrm{a}$ & $0.47(0.04) \mathrm{a}$ \\
\hline $\mathrm{NW}$ & $2.71(0.11) \mathrm{b}$ & $3.33(0.12) \mathrm{a}$ & $0.57(0.23) \mathrm{a}$ \\
\hline $\mathrm{S}$ & $3.71(0.22) \mathrm{c}$ & $4.40(0.26) \mathrm{b}$ & $1.19(0.11) \mathrm{b}, \mathrm{c}$ \\
\hline $\mathrm{NE}$ & $3.74(0.18) \mathrm{c}$ & $4.83(0.28) \mathrm{b}$ & $0.98(0.16) \mathrm{b}$
\end{tabular}

Values within the same column followed by different letter are statistically different $\mathrm{P}<0.05$, Duncan test.

Cupressus arizonica was the only species that was derived entirely from artificial regeneration and was found in all aspects except the Northeastern. Analysis of variance revealed that averages of height and DBH between aspects differed significantly with the highest mean value for height $3.47 \mathrm{~m}$ on the Southern and for DBH $6.28 \mathrm{~cm}$ on the
Northwestern aspects. Crown projection had the highest value on the Northwestern and lowest on the Northern aspects. Finally, correlation between height and DBH was significant $\left(r^{2}=0.78\right)$ and between height and crown projection was $r^{2}=0.66$. On the other hand, correlation between $\mathrm{DBH}$ and crown projection was significantly weak.

Table 3. Effect of aspect on height, diameter at breast height (DBH) and crown projection of Cupressus arizonica

\begin{tabular}{cccc}
\hline ASPECT & Height $(\mathbf{m})$ & DBH $(\mathbf{c m})$ & Crown projection $\left(\mathbf{m}^{2}\right)$ \\
\hline $\mathrm{N}$ & $1.91(0.99) \mathrm{a}$ & $4.43(0.18) \mathrm{a}$ & $0.50(0.04) \mathrm{a}$ \\
\hline $\mathrm{SW}$ & $2.00(0.62) \mathrm{a}$ & $3.60(0.17) \mathrm{a}$ & $0.81(0.07) \mathrm{a}$ \\
\hline $\mathrm{SE}$ & $2.36(0.82) \mathrm{a}$ & $3.76(0.13) \mathrm{a}$ & $1.67(0.15) \mathrm{b}$ \\
\hline $\mathrm{NW}$ & $3.30(0.10) \mathrm{b}$ & $3.95(0.15) \mathrm{a}$ & $2.85(0.45) \mathrm{c}$ \\
\hline $\mathrm{S}$ & $3.47(0.19) \mathrm{b}$ & $6.28(0.36) \mathrm{b}$ & $1.5(0.11) \mathrm{b}$
\end{tabular}

Values within the same column followed by different letter are statistically different $P<0.05$, Duncan test

\section{Discussion}

Post-fire regeneration of Pinus brutia in the study area was as successful as in Samos (Thanos and Markou, 1991) and Thasos island (Spanos et al., 2001). Pinus brutia is an obligate re-seeder and a typical east Mediterranean tree species. Therefore, natural regeneration is the best choice for restoration of fire-affected pinewoods. The aspect of stands affected the revegetation process which was more successful in the Northern aspect. This result, by many researchers, is attributed to the fact that in the Northern aspect stands extensive human interventions, like planting and soil ripping, were carried out due to the favorable soil conditions (Tsitsoni et al., 2004; Spanos et al., 2010; Tsitsoni et al., 2010). According to Gong et al., (2008) at the Northern aspect stands there is increased productivity and species diversity than in Southern aspect ones. Additionally, Omary (2011) in a similar research for Pinus halepensis found that Northern and Western aspects have more favorable moisture content and longer solar radiation periods.

Cupressus sempervirens, which pre-existed in the research area, as well as Pinus brutia, dominated at poorer soils (Grigoriadis et al. 2009). In order to enrich soil properties a mixture with other species is necessary because cypress alone provides small quantities of litter (Brofas et al., 2006). Thus, Cupressus sempervirens must be considered a proper species for introduction in pure stands of Pinus brutia. The mixed stands have advantages in comparison to the pure because they exploit the soil better, and are more resistant against wildfires (Zagas et al., 2001).

According to Spanos et al. (2010), the main broadleaved species in the area should be Quercus pubescens. Even though this species was planted in the major part of the burnt area, it exhibited low growth rate. Due to the current literature (Maestre et al., 2002; Pardos et al., 2003) the survival of oak species is difficult and often uncertain. The major problem for their establishment is the failure of the root system to absorb water and nutrients and grow immediately after planting. Also limiting factors for the seedlings growth is the lack of moisture during the summer and the degraded soil.

The natural regeneration of the Kedrinos lofos forest, 14 years after the forest fire, is considered as successful. It is worth noting that most plant communities can regenerate in a short period (5-20 years) after fires in the Mediterranean basin (Trabaud, 1994; Tavsanoglou and Gürcan, 2009). As Lavorel, (1999) indicates, most of the species found in pre-fire communities emerge in the early post-fire years and the ecosystem returns to its initial vegetation structure.

\section{Conclusion}

The forest of Kedrinos lofos is composed of a mixture of natural regeneration of Pinus brutia and artificial regeneration of Cupressus sempervirens and Cupressus 
arizonica and, in some cases, with broadleaved species. Generally, the growth of Pinus brutia seems to be much better in comparison to other species. Specifically, the indroduction of non-native species, as Cupressus arizonica must be avoided due to the low participation and growth rate. Aspect affected the mixture of regenerated and planted species, but did not seem to affect the growth of Pinus brutia to a great extent. It is also necessary to mention that the growth of planted species was influenced by aspect. The saplings, 14 years after the forest fire, exhibited significant vitality and developmental tendency. Silvicultural treatments, such as thinning or pruning, are necessary due to the acceleration of the stands development. Plantations with native broadleaved species, in order to improve soil conditions and the aesthetic value of the landscape, should be the only intervention in the future. Finally, when conducting restoration projects, both in the research area and the wider Mediterranean basin it is wise to learn from past disasters in order to achieve natural rehabilitation.

\section{Acknowledgements}

Many thanks to Professor Panagiotis Stefanidis for his assistance with field work and to Mr. Christos Damaskos for his help with the written English in this paper.

\section{References}

Arianoutsou M. (1984), Post fire successional recovery of a phryganic Mediterranean ecosystem, Acta Oecologica / Oecologia Plantarum, 5, 378-394.

Bengtsson J., Nilsson S., Franc A. and Menozzi P. (2000), Biodiversity, disturbances, ecosystem function and management of European forests, Forest Ecology and Management, 132, 39-50.

Boydak M. (2004), Silvicultural characteristics and natural regeneration of Pinus brutia Ten - a review, Plant Ecology, 171, 153-163.

Brofas F., Karetsos G., Dimopoulos P. and Tsagari C. (2006), The natural environment of Cupressus sempervirens in Greece as a basis for its use in the Mediterranean region, Land Degradation \& Development , 17, 645-659.

Dafis S. (1987), Ecology of Pinus halepensis and Pinus brutia forests (in Greek), In:Proceedings of the 1st Scientific Conference on Pinus halepensis and Pinus brutia forests, Hellenic Forestry Society (Eds), Thessaloniki, 17-25.

Dafis S. (1991), Restoration of degraded forests at the area of mount "Cholomontas" (NE Chalkidiki). Scientific Annals of Faculty of Forestry and Natural Environment, Aristotle University of Thessaloniki, 22, 145-153.

De Las Heras J., González-Ochoa A., López-Serrano F. and Simarro M.E. (2004), Effects of silviculture treatments on vegetation after fire in Pinus halepensis Mill. woodlands (SE Spain), Annals of Forest Science, 61,661-667.

Emberger I. (1959), Orientations actuelles au Service de la C.G.V. de la ceuntographie phytosiciologique appliqué. Bull. Serv. Carte Phytogeorg. Ser. B. IV: fasc.2.

Espelta J.M., Retana J. and Habrouk A. (2003), Resprouting patterns after fire and response to stool cleaning of two coexisting Mediterranean oaks with contrasting leaf habits on two different sites, Forest Ecology and Management, 179, 401-414.
Grigoriadis N., Galatsidas S. and Takos I. (2009), Post fire regeneration conditions in the urban forest of Thessaloniki, 10 years after fire, Ecology \& Safety, 3, 75-81.

Gong X., Brueck H., Giese M., Zgang L., Sattelmacher B. and Lin S. (2008), Slope aspect has effects on productivity and species composition of hilly grassland in the Xilin River Basin, Inner Mongolia, China, J Arid Land Environment, 72, 483-493.

Kailidis D. (1997), The fire of forest-park of Thessaloniki at 6-7 July 1997, Technical report, 24.

Köppen W. (1931), Grundriss der Klimakunde, Berlin: Walter de Gruyter.

Lavorel S. (1999), Ecological diversity and resilience of Mediterranean vegetation to disturbance, Diversity and Distributions, 5, 3-13.

Lamb D. and Guilmour D. (2003), Rehabilitation and restoration of degraded forests,IUCN, Gland, Switzerland and Cambridge, UK and WWF, Gland Switzerland.

Leibundgut H. (1959), Über Zweck und Methodik der Strukturund Zuwachsanalyse vonUrwäldern. Schweiz. Z. Forstwes. 110, 3: 111-124.

Maestre F.T., Bautista S., Cortina, J., Dıaz G., Honrubia M.and Vallejo R. (2002), Microsite and mycorrhizal inoculum effects on the establishment of Quercus coccifera in a semi-arid degraded steppe, Ecological Engineering 19, 289 - 295

Moreira F., Arianoutsou M., Vallejo R., De Las Heras J., Corona P., Xanthopoulos G., Fernandes D. and Papageorgiou K. (2012), Setting the scene for post-fire management, Post-fire management and restoration of Southern European forests, Moreira F. et al. (eds) Springer, Germany, pp 329.

Moreira F., Catry F., Lopes T., Bugalho M. and Rego F. (2009), Comparing survival and size of resprouts and planted trees for post-fire forest restoration in central Portugal, Ecological Engineering, 35, 870-873.

Moreira F. and Vallejo R. (2009), What to do after fire? Post-fire restoration, Living with wildfires: what science can tell us, Birot Y. (ed) EFI Discussion Paper 15, EFI, Joensuu.

Naveh Z. (1991), The role of fire in Mediterranean vegetation, Botanica Chronika (Greece), 10, 385-405.

Norusis M.J. (1994), SPSS Professional Statistics. 6.1 SPSS Inc, Chicago Illinois, USA. Omary A. (2011), Effects of aspect and slope position on growth and nutritional status of planted Aleppo pine (Pinus halepensis Mill.) in a degraded land semiarid areas of Jordan, New Forests, 42, 285-300.

Ozdemir T. (1977), Antalya bolgesinde kizilcam (Pinus brutia Ten) ormanlarinin tabii genclestirme olanaklari uzerine arastirmalar. I.U. Orman Fakultesi Dergisi A, 27, 243-293.

Palahi M. and Birot Y. (2009), A Mediterranean Forest Research Agenda- MFRA 2010- 2020, pp 32.

Pardos M., Royo A., Gil L. and Pardos J.A. (2003), Effect of nursery location and outplanting date on field performance of Pinus halepensis and Quercus ilex seedlings, Forestry ,76, 67-81.

Pausas J.G., Blade C., Valdecantos A., Seva J.P., Fuentes D., Alloja J.A., Valagrosa A., Bautista S., Cortina J. and Vallejo R. (2004), Rehabilitation and restoration of Mediterranean landscapes of Spain: new perspectives for an old practice - a review, Plant Ecology, 171, 209-220.

Pausas J.G. and Vallejo V.R. (1999), The role of fire in European Mediterranean Ecosystems, Remote sensing of large wildfires in the European Mediterranean basin, Chuvieco E. (eds), Springer, Berlin, pp.3-16. 
Pausas J.G., Liovet J., Rodrigo A. and Vallejo R. (2008), Are wildfires a disaster in the Mediterranean basin?-A review, International journal of wildland fire, 17, 713-723.

Spanos I. (1992), Structure analysis and natural regeneration of Pinus brutia forests in Thasos, Dissertation, Aristotle University of Thessaloniki. (In Greek with English summary).

Spanos I. and Spanos K. (1996), Postfire establishment and survival of Pinus brutia in the island Thasos, 2nd Balkan Scientific Conference, Investigation, Preservation and Utilization of Forest Resources, Sofia, Bulgaria, 1, 163-168.

Spanos I., Hatzifilipidis G., Zagas T., Hatzistathis A., Pinakidis I., Athanasiadis V. and Stergiopoulos I. (2000), Post-fire establishment of plantings in the suburban forest park of Thessaloniki: first results two years after the great fire. Forest Research, 13, 11-25,( in Greek with English summary)

Spanos I, Daskalakou E, Thanos C. (2000), Postfire, natural regeneration of Pinus brutia forests in Thasos island, Greece, Acta Oecologica, 21, 13-20.

Spanos I., Radoglou K. and Raftoyiannis Y. (2001), Site quality effects on post-fire regeneration of Pinus brutia forest on a Greek island, Applied Vegetation Science, 4, 229-236.

Spanos I., Ganatsas P., and Tsakaldimi M. (2010), Evaluation of postfire restoration in suburban forest of Thessaloniki, Northern Greece, Global Nest Journal, 12, 390-400.

Stephan K., Miller M., and Dickinson M. (2010), First-order fire effects on herbs and shrubs: present knowledge and process modeling needs, Fire ecology, 6, 95-114.

Tavsanoglou C. and Gürcan B. (2009), Post fire regeneration of a Pinus brutia (Pinaceae) forest in Marmaris national park, Turkey, International Journal of Botany, 5, 107-111.

Thanos C., Marcou S., Christodoulakis D. and Yiannitsaros S. (1989), Early post-fire Regeneration in Pinus brutia forest ecosystem of Samos island (Greece), Acta Oecologica (Oecologia Plantarum), 10, 79-94.

Thanos C. and Marcou S. (1991), Postfire regeneration in Pinus brutia forest ecosystems of Samos island (Greece): 6 years after, Acta Oecologica, 10, 633-642.

Thanos C. and Doussi M. (2000), Postfire regeneration of Pinus brutia forests, Ecology, Biogeography and Management of Pinus halepensis and P. brutia Forest Ecosystems in the Mediterranean Basin, Neeman G. and Trabaud L. (eds). Backhuys Publishers, Leiden, The Netherlands, 291-301.

Trabaud L. (1994), Postfire plant community dynamics in the Mediterranean Basin, The role of fire in Mediterranean Type Ecosystems, Moreno J.M. and Oechel W.C. (eds), Ecological Studies, Springer-Verlag, New York, pp. 1-15.

Tsitsoni T., Ganatsas P., Zagas T. and Tsakaldimi M. (2004), Dynamics of postfire regeneration of Pinus brutia Ten. in an artificial forest, Plant Ecology, 171, 165-174.

Tsitsoni T., Tsakaldimi M., Simeliadou E. and Fouska M. (2010), Structural analysis of mixed stands coming from natural regeneration and plantations after fire, Web ecology, 10, 32-37.

Vallejo R. (2005), Restoring Mediterranean Forests, Forest Restoration in Landscapes, part D, 313-319.

Zagas T. (1987), Research of Pinus halepensis natural regeneration after fire at Mount "Pateras" (Attiki, Greece). Scientifc Annals of Faculty of Forestry and Natural Environment, Aristotle University of Thessaloniki, 11, 303-327.
Zagas T., Gkanatsas P., Tsitsoni T. and Hatzistathis A. (1998), Rehabilitation of forest degraded ecosystems protected from grazing, In: Proceedings of the 8th Hellenic Forestry Conference on Modern Problems of Forestry, Alexandroupoli, Greece, 401-408.

Zagas T., Tsitsoni T. and Hatzistathis A. (2001), The mixed forests of Greece, Silva Gandavensis, 66, 68-75.

Zagas T. (2008), Contribution of periurban forests to the viability of urban space, Buildings, Energy and the Environment, Kosmopoulos P (ed), University Studio Press, Thessaloniki, 4560. 